\title{
Initial Changes in Refilled Lysimeters Built with Metal Polluted Topsoil and Acidic or Calcareous Subsoils as Indicated by Changes in Drainage Water Composition
}

\author{
Jörg Luster • Manoj Menon • Sandra Hermle • \\ Rainer Schulin • Madeleine S. Günthardt-Goerg • \\ Bernd Nowack
}

Received: 15 January 2007 /Revised: 25 August 2007 / Accepted: 28 September 2007 / Published online: 29 November 2007

(C) Springer Science + Business Media B.V. 2007

\begin{abstract}
Soil translocation for recultivation of soil removed from construction sites and for the preparation of refilled lysimeters inevitably involves disturbance of soil structure, and, if intermediate storage is included, also drying and rewetting of the soil. We report on an experiment with model forest ecosystems, where uncontaminated forest subsoils were covered with non-contaminated or freshly heavy metal (mainly $\mathrm{Zn}$ and $\mathrm{Cu}$ ) contaminated topsoil in
\end{abstract}

J. Luster $(\bowtie) \cdot$ S. Hermle $\cdot$ M. S. Günthardt Goerg

Swiss Federal Institute for Forest, Snow,

and Landscape Research,

Zürcherstrasse 111,

CH 8903 Birmensdorf, Switzerland

e mail: joerg.luster@wsl.ch

M. Menon $\cdot$ R. Schulin $\cdot$ B. Nowack

Institute of Terrestrial Ecosystems, ETH Zurich,

Universitätstrasse 16,

CH 8092 Zürich, Switzerland

M. Menon

Department of Geological Sciences and Engineering,

University of Nevada,

Reno, NV 89557, USA

B. Nowack

EMPA Swiss Federal Laboratories for Materials Testing

and Research,

Lerchenfeldstrasse 5,

CH 9014 St. Gallen, Switzerland large lysimeters. Monitoring of the chemical composition of the drainage water revealed two distinct soil conditioning phases. During an initial phase of about a year strongly elevated nitrate and sulfate concentrations occurred that were attributed to a mineralisation flush caused by the increased accessability of mineralisable nitrogen and sulfur in destroyed aggregates. These effects were significantly larger in lysimeters with calcareous subsoil than in those with acidic subsoil. The second phase was characterised by a gradual decrease in dissolved organic carbon and sulfate concentrations, in particular in the acidic subsoil. This decrease may be attributed to the depletion of pools made accessible during aggregate destruction or the formation of new aggregates. These chemical changes had only little effects on the concentrations of copper and zinc in the drainage water. Based on our results, it can be concluded that large refilled lysimeters can be used for many purposes without risk of compromised results, if a conditioning phase of about 1 year with sufficiently moist soil conditions is respected. Nevertheless, gradual changes in soil chemical characteristics still occur after this initial phase. Implications for the recultivation of sites using relocated soils are discussed.

Keywords Drying and rewetting of soils .

Heavy metals · Mineralisation of soil organic matter .

Refilled lysimeters · Soil relocation · Soil solution ·

Soil structure 


\section{Introduction}

The recultivation of material removed from construction sites, waste deposits or open-cast mines involves the excavation of large amounts of soil material, its temporary storage and reuse in artificially built soils (Schmidt and Bannick 1996). The same is true, at a smaller scale, for experiments with refilled lysimeters, which provide a means to conduct factorially designed experiments with large plants or small ecosystems under controlled but relevant climate and soil conditions (Abrahamsen and Erstad 1995), bridging the gap between laboratory or greenhouse systems on one hand, and monolith lysimeters or the field on the other hand (Bergström and Stenström 1998).

Soil translocation inevitably involves disturbance or destruction of soil structures, and, if intermediate storage is included, also drying and rewetting of the soil (Zwölfer et al. 1991). Not taking into account the effects that this has on soil properties, can seriously compromise the results of studies performed with freshly reconstituted soil (Johnson et al. 1995). Here we focus on biologically mediated chemical processes in well aerated soil material rather than on the effects of compaction and waterlogging during intermediate storage on soil fertility. The latter aspect has been studied extensively and found its way into soil protection regulations and recommendations for practitioners (Zwölfer et al. 1991). A well known effect is a flush of nitrogen and carbon mineralization occurring upon rewetting of dried or sieved soil (Birch 1958). It leads to high nitrate and dissolved organic carbon (DOC) concentrations in soil solution. Highly elevated nitrate concentrations led to a negative growth response of pine seedlings to $\mathrm{N}$ fertilization in a pot experiment as opposed to a positive response in the field (Johnson et al. 1995). The effect is ascribed to a large amount of available $\mathrm{C}$ and $\mathrm{N}$ in dead microorganisms (Powlson 1980) or in liberated soil organic matter and ammonium in destroyed aggregates (Franzluebbers 1999; Ross and Hales 2003). The strong increase in nitrate concentrations upon aggregate destruction does not surprise considering the significant effects that rather small soil disturbances like footprints or formation of trenches can have on nitrogen mineralization rates (Miller et al. 1992; Ross and Hales 2003). There is agreement that this process is an initial one, and that the effects cease with time. This is due to consumption and leaching of the liberated pool of easily mineralizable material (Ross and Hales 2003) and to the formation of new aggregates (Bergström and Stenström 1998). However, indications of how long elevated solute concentrations occur are rare, in particular for large refilled lysimeters. Johnson et al. (1995) observed nitrate concentrations in unfertilised pots going down from $1 \mathrm{mM}$ to a few $\mu \mathrm{M}$ within 30 weeks. For a column experiment, Franzluebbers (1999) reported a ceasing of enhanced DOC concentrations after a conditioning phase of 10 days. Sogn and Abrahamsen (1998) observed enhanced leaching of sulfate in the first year after refilling lysimeters with forest soil material.

In a lysimeter experiment we studied the effects of subsoil type, irrigation $\mathrm{pH}$ and topsoil metal contamination on plant and soil parameters in model forest ecosystems. The lysimeters were filled with two different combinations of top and subsoils as substrates that were compatible with respect to texture, $\mathrm{pH}$ and soil organic matter (SOM) content. Results from the second phase of the experiment with rather stable soil conditions can be found elsewhere (Brunner et al. 2007; Frey et al. 2006; Hermle et al. 2006, 2007; Menon et al. 2005; Nowack et al. 2006; Rais 2005). Here, we report changes in drainage water composition as indicators of changes in the subsoil during the experiment.

\section{Materials and Methods}

\subsection{Lysimeter Experiment}

The model ecosystems were established in the opentop chamber (OTC) facility of the Swiss Federal Institute for Forest, Snow and Landscape Research, WSL, Birmensdorf, Switzerland (450 m a.s.l.). Each lysimeter was planted randomly with 14 trees (six Picea abies (L.) Karst. (3-year-old trees); four Populus tremula cuttings without roots; two Salix viminalis rooted cuttings; two Betula pendula rooted cuttings; all the rooted cuttings were 6 months old and planted before bud break) and understorey plants. Each of the 16 OTC contained two lysimeters. In the growing seasons (May through October), lysimeters in eight OTCs received irrigation with synthetic rain of $\mathrm{pH} 5.5$ and those in the other eight synthetic rain of $\mathrm{pH} 3.5$, and the roofs of the OTC closed automatically 
during rain events to exclude natural precipitation. The ionic composition of the synthetic rain mimicked the 30 years mean of the local natural rain $\left(70 \mathrm{NH}_{4}\right.$, $70 \mathrm{NO}_{3}, 3.2 \mathrm{PO}_{4}, 17 \mathrm{Cl}, 3.1 \mathrm{SO}_{4}, 4.3 \mathrm{Na}, 7.7 \mathrm{~K}, 5 \mathrm{Ca}$, $1.3 \mathrm{Mg}, 0.15 \mathrm{Zn}[\mu \mathrm{mol} / \mathrm{L}])$. The $\mathrm{pH}$ was adjusted with $\mathrm{HCl}$. The amount of the irrigation was adjusted to keep the water potential above $-300 \mathrm{hPa}$. If this was achieved in the topsoil, potentials in the subsoil were generally above $-50 \mathrm{hPa}$, except during the first year, when subsoil potentials were mostly between -50 and $-250 \mathrm{hPa}$. According to a comparison between tensiometer and TDR readings, a potential of $-300 \mathrm{hPa}$ corresponded to a water content of 0.18 , 0.16 , and $<0.19$ for the topsoil, the calcareous, and the acidic subsoil, respectively. A potential of $-50 \mathrm{hPa}$ corresponded to a water content of $0.23,0.22$, and 0.3 , respectively. During winter (November through April), the roofs remained open and the lysimeters received natural precipitation. Four additional lysimeters without OTC received natural precipitation throughout the year. Table 1 gives an overview of the amounts of irrigation and natural precipitation received by the lysimeters. More details on the lysimeter facility can be found in Landolt (2001) and Hermle et al. (2006).

The lysimeters had a surface area of $3 \mathrm{~m}^{2}$ and a depth of $1.5 \mathrm{~m}$. They were filled as follows. A $50 \mathrm{~cm}$ drainage layer consisted of three sublayers of firedried quartz gravel with grain sizes of 5-8, 1.5-2.2, and $0.7-1.2 \mathrm{~mm}$. It was composed of $99 \% \mathrm{SiO}_{2}, 0.4 \%$ $\mathrm{Al}_{2} \mathrm{O}_{3}, 0.2 \%$ of $\mathrm{Na}_{2} \mathrm{O}+\mathrm{K}_{2} \mathrm{O}$, and $0.05 \%$ each of $\mathrm{CaO}$ $+\mathrm{MgO}, \mathrm{Fe}_{2} \mathrm{O}_{3}$, and $\mathrm{TiO}_{2}$, and was acid washed to remove impurities. Above the drainage packing there was an $80 \mathrm{~cm}$ layer of subsoil and a $15 \mathrm{~cm}$ layer of topsoil. The subsoil was either an acidic loamy sand from a Haplic Alisol near Eiken, Aargau, Switzerland, or a calcareous sandy loam originating from a Calcaric Fluvisol near Vogelsang-Brugg, Aargau, Switzerland. The topsoil was a slightly acidic loam from Birr, Aargau, Switzerland. The sequences of soil layers were representative of an acidic soil, in which the topsoil $\mathrm{pH}$ was raised by agricultural practice, and a calcareous soil with a decarbonated topsoil, respectively. Some physical and chemical characteristics of the soil materials are given in Table 2. For more data see Nowack et al. (2006). Before being filled into the lysimeters, the soils were stored near the experimental site, protected from precipitation (Brugg for 1 year, Eiken and Birr for less than 1 month). The subsoils were filled in September 1999 to settle down during the following winter. The topsoil was mixed with a manure mixer and filled in January 2000. In March 2000 , the roofs of the OTC were closed to allow the topsoil to dry, before end of April 2000 in half of the lysimeters the filter dust from a secondary non-ferrous metal smelter was worked into the topsoil layer. The filter dust increased the topsoils natural heavy metal (HM) contents (Table 2) to $640 \mathrm{mg} / \mathrm{kg} \mathrm{Cu}, 3000 \mathrm{mg} / \mathrm{kg}$ $\mathrm{Zn}, 10 \mathrm{mg} / \mathrm{kg} \mathrm{Cd}$, and $90 \mathrm{mg} / \mathrm{kg} \mathrm{Pb}$. Finally, the vegetation was planted in May 2000. Unavoidably, this led to some structural disturbance in the topsoil. This, however, was the same in all treatments, and, thus, helped to balance a possible structural effect by the manual mixing of topsoil with dust in the heavy metal treatments. Irrigation started immediately after planting.

The combination of contaminated vs. uncontaminated topsoil, acidic vs. calcareous subsoil and irrigation with rain $\mathrm{pH} 5.5$ vs. rain $\mathrm{pH} 3.5$ resulted in eight different treatments that were replicated each four times, using a Latin square arrangement of the OTC with respect to irrigation and topsoil, while each OTC hosted one lysimeter with acidic subsoil and one lysimeter with calcareous subsoil. The additional treatments with natural precipitation (lysimeters outside OTC) were done only once.

\subsection{Tensiometry, Sampling and Analysis of Drainage Water}

In each OTC lysimeter, eight tensiometers were installed vertically, two each at 12.5, 37.5, 62.5 and $87.5 \mathrm{~cm}$ depths (middle of ceramic cups). Soil water potentials were recorded once a week during the growing season, using the method of Marthaler et al. (1983). No soil moisture data were recorded for the lysimeters receiving natural precipitation throughout the year.

Drainage water was collected in three polyethylene tanks each from the bottom of each lysimeter. The water collected from the three containers of the same lysimeter was pooled. Samples of the collected water were either analysed individually, or combined with the other samples of the same treatment for analysis. The volume of the drainage water was recorded consistently during the growing season, while this was not possible during the winter. For a given sampling, discharge in $\mathrm{L} \mathrm{m}{ }^{2}$ day ${ }^{1}$ was calculated by 
Table 1 Average daily rates of natural precipitation, irrigation, and drainage discharge, as well as average water potentials for different time periods; significant differences between acidic and calcareous subsoils are indicated next to the numbers, significant differences between irrigated and non irrigated lysimeters in separate columns; ${ }^{* * *} p<0.0001,{ }^{*} p<0.001,{ }^{*} p<0.01,\left({ }^{*}\right) p<0.05$, ns not significant

\begin{tabular}{|c|c|c|c|c|c|c|c|c|c|c|c|c|}
\hline \multirow[t]{3}{*}{ Time period } & \multirow{3}{*}{$\begin{array}{l}\text { Natural } \\
\text { precipitation }\end{array}$} & \multirow{3}{*}{$\begin{array}{l}\text { Irrigation } \\
\\
{\left[\mathrm{L} \mathrm{m}^{2}\right.} \\
\left.\text { day }^{1}\right]\end{array}$} & \multicolumn{4}{|c|}{$\begin{array}{l}\text { Water potential in irrigated lysimeters } \\
\text { (mean } \pm \text { standard deviation) }\end{array}$} & \multicolumn{6}{|c|}{ Drainage water discharge } \\
\hline & & & \multicolumn{2}{|l|}{$88 \mathrm{~cm}$} & \multicolumn{2}{|l|}{$38 \mathrm{~cm}$} & \multicolumn{2}{|c|}{$\begin{array}{l}\text { Irrigation (mean } \pm \\
\text { standard deviation) }\end{array}$} & \multicolumn{2}{|c|}{$\begin{array}{l}\text { Natural precipitation } \\
\text { (mean } \pm \text { standard } \\
\text { deviation) }\end{array}$} & \multicolumn{2}{|c|}{$\begin{array}{l}\text { Irrigation vs. natural } \\
\text { precipitation }\end{array}$} \\
\hline & & & $\begin{array}{l}\text { Acidic } \\
\text { subsoil } \\
\text { [hpa] }\end{array}$ & $\begin{array}{l}\text { Calcareous } \\
\text { subsoil } \\
{[\text { hpa }]}\end{array}$ & $\begin{array}{l}\text { Acidic } \\
\text { subsoil } \\
\text { [hpa }]\end{array}$ & $\begin{array}{l}\text { Calcareous } \\
\text { subsoil } \\
{[\mathrm{hpa}]}\end{array}$ & $\begin{array}{l}\text { Acidic } \\
\text { subsoil } \\
{\left[\mathrm{L} \mathrm{m}^{2}\right.} \\
\left.\text { day }^{1}\right]\end{array}$ & $\begin{array}{l}\text { Calcareous } \\
\text { subsoil } \\
{\left[\mathrm{L} \mathrm{m}^{2}\right.} \\
\left.\text { day }{ }^{1}\right]\end{array}$ & $\begin{array}{l}\text { Acidic } \\
\text { subsoil } \\
{\left[\mathrm{L} \mathrm{m}^{2}\right.} \\
\left.\text { day }^{1}\right]\end{array}$ & $\begin{array}{l}\text { Calcareous } \\
\text { subsoil } \\
{\left[\mathrm{L} \mathrm{m}^{2}\right.} \\
\left.\text { day }{ }^{1}\right]\end{array}$ & $\begin{array}{l}\text { Acidic } \\
\text { subsoil }\end{array}$ & $\begin{array}{l}\text { Calcareous } \\
\text { subsoil }\end{array}$ \\
\hline $\begin{array}{l}1.10 .1999 \\
15.3 .2000\end{array}$ & 2.80 & 2.802 & & & & & & & & & & \\
\hline $\begin{array}{l}15.3 . \\
22.5 .2000\end{array}$ & 2.45 & 1 & & & & & & & & & & \\
\hline $\begin{array}{l}22.5 . \\
4.9 .2000\end{array}$ & 4.69 & 3.14 & $\begin{array}{l}-139 \pm \\
94\end{array}$ & $-95 \pm 61$ & $\begin{array}{c}-172 \pm \\
90\end{array}$ & $-132 \pm 64$ & $\begin{array}{c}0.17 \pm \\
0.12\end{array}$ & $0.20 \pm 0.17$ & $\begin{array}{c}0.76 \pm \\
0.13\end{array}$ & $0.69 \pm 0.17$ & $*$ & $(*)$ \\
\hline $\begin{array}{l}4.9 . \\
8.11 .2000\end{array}$ & 3.20 & 4.15 & $-18^{3}$ & $-17^{3}$ & $-27^{3}$ & $-22^{3}$ & $\begin{array}{r}1.62 \pm \\
0.67\end{array}$ & $1.51 \pm 0.67$ & $\begin{array}{r}1.20 \pm \\
0.36\end{array}$ & $1.03 \pm 0.44$ & ns & ns \\
\hline $\begin{array}{c}8.11 .2000 \\
13.4 .2001\end{array}$ & 3.18 & 3.182 & & & & & & & & & & \\
\hline $\begin{array}{c}13.4 .2001 \\
18.7 .2001\end{array}$ & 3.44 & 2.81 & $\begin{array}{r}-66 \pm \\
46(*)\end{array}$ & $\begin{array}{r}-355 \pm \\
212(*)\end{array}$ & $\begin{array}{c}-47 \pm \\
30\end{array}$ & $\begin{array}{c}-141 \pm \\
123\end{array}$ & $\begin{array}{c}0.96 \pm \\
1.28\end{array}$ & $\begin{array}{c}0.31 \pm \\
0.35\end{array}$ & $\begin{array}{c}0.59 \pm \\
0.45\end{array}$ & $\begin{array}{c}0.50 \pm \\
0.35\end{array}$ & ns & ns \\
\hline $\begin{array}{c}18.7 .2001 \\
6.11 .2001\end{array}$ & 3.62 & 5.5 & $\begin{array}{l}-18 \pm \\
3^{*}\end{array}$ & $-24 \pm 4^{*}$ & $\begin{array}{l}-28 \pm \\
3^{*}\end{array}$ & $-35 \pm 5^{*}$ & $\begin{array}{l}2.28 \pm \\
1.44(*)\end{array}$ & $\begin{array}{l}1.41 \pm 1.05 \\
(*)\end{array}$ & $\begin{array}{c}0.68 \pm \\
0.96\end{array}$ & $0.41 \pm 0.59$ & $* * *$ & $(*)$ \\
\hline $\begin{array}{c}6.11 .2001 \\
15.5 .2002\end{array}$ & 2.36 & 2.362 & & & & & & & & & & \\
\hline $\begin{array}{r}15.5 .2002 \\
2.7 .2002\end{array}$ & 3.56 & 3.62 & $\begin{array}{c}-33 \pm \\
12^{*}\end{array}$ & $\begin{array}{r}-113 \pm \\
115^{*}\end{array}$ & $\begin{array}{c}-145 \pm \\
118\end{array}$ & $-211 \pm 169$ & $\begin{array}{c}0.71 \pm \\
0.60\end{array}$ & $0.50 \pm 0.57$ & $\begin{array}{c}0.66 \pm \\
0.54\end{array}$ & $0.29 \pm 0.42$ & ns & ns \\
\hline $\begin{array}{l}2.7 .2002 \\
24.10 .2002\end{array}$ & 4.92 & 5.59 & $\begin{array}{c}-16 \pm 2 \\
(*)\end{array}$ & $\begin{array}{l}-35 \pm 21 \\
(*)\end{array}$ & $\begin{array}{c}-28 \pm \\
3 * *\end{array}$ & $-37 \pm 4^{* *}$ & $\begin{array}{c}2.05 \pm \\
0.72 *\end{array}$ & $\begin{array}{c}1.02 \pm \\
0.74^{*}\end{array}$ & $\begin{array}{r}0.77 \pm \\
1.06\end{array}$ & $0.58 \pm 0.96$ & $* *$ & ns \\
\hline $\begin{array}{c}24.10 .2002 \\
7.5 .2003\end{array}$ & 2.60 & 2.602 & & & & & & & & & & \\
\hline $\begin{array}{l}\text { 7.5.2003 } \\
18.9 .2003\end{array}$ & 4.35 & 9.05 & $\begin{array}{c}-17 \pm \\
3^{*}\end{array}$ & $-32 \pm 22 *$ & $\begin{array}{c}-35 \pm \\
18\end{array}$ & $-41 \pm 14$ & $\begin{array}{c}1.89 \pm \\
1.12\end{array}$ & $1.41 \pm 1.01$ & $\begin{array}{c}0.04 \pm \\
0.03\end{array}$ & $0.04 \pm 0.03$ & $* *$ & $*$ \\
\hline $\begin{array}{c}18.9 .2003 \\
5.12 .2003\end{array}$ & 2.67 & 2.672 & & & & & & & & & & \\
\hline
\end{tabular}

${ }^{1}$ OTC closed.

${ }^{2}$ OTC received natural precipitation.

${ }^{3}$ Only one sampling.

dividing the volume first by the area of a lysimeter and then by the number of days since the last sampling.

Individual or pooled drainage water samples were filtered $(0.45 \mu \mathrm{m})$, and analysed for $\mathrm{pH}$ (potentiometrically, electrode: Radiometer pHC4000-8), electrical conductivity (cell: Radiometer XE170), DOC (elemental analyser, Shimadzu TOC-V), inorganic anions (ion chromatography, Dionex DX-120) and total element concentrations (inductively coupled plasma mass spectrometry, Perkin Elmer ELAN 6000).

\subsection{Soil Respiration}

Soil respiration was measured in all lysimeters in August 2000, June 2001, and August 2001. In June and August 2002 and 2003, soil respiration was measured only in the irrigated lysimeters. The measurements were taken from pre-installed soil collars with a diameter of $10.2 \mathrm{~cm}$ and a depth of $4.5 \mathrm{~cm}$. Four soil collars were installed in each lysimeter, avoiding placements close to a tree or at the edge of the lysimeter, and were kept free of 
Table 2 Selected physical and chemical characteristics of the soil materials used to build the lysimeter soils (from Nowack et al. 2006); measurements were taken from dried and sieved composite samples at the beginning of the experiment

\begin{tabular}{|c|c|c|c|}
\hline & Topsoil & Acidic subsoil & Calcareous subsoil \\
\hline Texture [\% sand; silt; clay $]^{1}$ & $36 ; 49 ; 15$ & $87 ; 8 ; 5$ & $74 ; 16 ; 10$ \\
\hline $\mathrm{pH}\left(0.01 \mathrm{M} \mathrm{CaCl}_{2}\right)^{2}$ & 6.4 & 4.2 & 7.4 \\
\hline $\mathrm{C}_{\text {inorg }}[\mathrm{g} / \mathrm{kg}]^{3}$ & $<1$ & $<1$ & 21 \\
\hline $\mathrm{C}_{\text {org }}[\mathrm{g} / \mathrm{kg}]^{3}$ & 15.1 & 3.2 & 11.2 \\
\hline $\mathrm{N}_{\text {tot }}[\mathrm{g} / \mathrm{kg}]^{3}$ & 1.5 & $<0.3$ & 0.6 \\
\hline $\mathrm{CEC}\left[\mathrm{mmol}_{\mathrm{c}} / \mathrm{kg}\right]^{3}$ & 102 & 31 & 134 \\
\hline Base saturation $[\%]^{3}$ & 99.9 & 35.9 & 99.9 \\
\hline $\mathrm{Cu}_{\text {tot }}[\mathrm{mg} / \mathrm{kg}]^{3}$ & 28 & 7.4 & 14 \\
\hline $\mathrm{Zn}_{\text {tot }}[\mathrm{mg} / \mathrm{kg}]^{3}$ & 97 & 39 & 58 \\
\hline $\mathrm{Cd}_{\text {tot }}[\mathrm{mg} / \mathrm{kg}]^{3}$ & 0.1 & $<0.2$ & 0.2 \\
\hline $\mathrm{Pb}_{\text {tot }}[\mathrm{mg} / \mathrm{kg}]^{3}$ & 37 & 13 & 19 \\
\hline
\end{tabular}

${ }^{1}$ Laboratory precision $\pm 0.5 \%$.

${ }^{2}$ Laboratory precision \pm 0.02 .

${ }^{3}$ Laboratory precision $\pm 10 \%$.

mosses and germinating plants. At a given measurement series, $\mathrm{CO}_{2}$ efflux from each collar was measured once, using a Li-6400 portable photosynthesis system (Li-Cor Inc., Lincoln, Nebraska) fitted directly with a $6400-09$ soil $\mathrm{CO}_{2}$ flux chamber. The total system volume was $991 \mathrm{~cm}^{3}$. Mixing in the chamber headspace was achieved with the gas analyzer mixing fan and the associated manifold. Efflux of $\mathrm{CO}_{2}$ from the soil was computed based on the rate of $\mathrm{CO}_{2}$ increase in the chamber headspace between $-10 \mathrm{ppm}$ and $+10 \mathrm{ppm}$ from the actual ambient $\mathrm{CO}_{2}$ concentration (Healy et al. 1996). For each measurement, soil temperature was recorded using a probe with a precision of $\pm 1.5^{\circ} \mathrm{C}$.

\section{Results}

\subsection{Drainage Discharge and Soil Moisture in the Irrigated OTC Lysimeters}

In the first summer, drainage discharge was very low until September (Table 1) with water potentials in the topsoil and both subsoils varying between -40 and $-250 \mathrm{hPa}$. In September the water potential at all soil depths rose to about $-20 \mathrm{hPa}$ and large amounts of drainage discharge were collected (Table 1). In 2001, until mid of July, irrigation was not sufficient leading to small amounts of drainage and water potentials down to $-550,-130$, and $-250 \mathrm{hPa}$ in the calcareous subsoils, acidic subsoils, and topsoils, respectively (data not shown). After this period, large amounts of drainage discharge were obtained. Water potentials in the subsoil were between -20 and $-50 \mathrm{hPa}$ with little temporal variation, and in the topsoil they varied between -25 and $-100 \mathrm{hPa}$. Both average drainage discharge and water potentials were significantly larger in the acidic than in the calcareous subsoil (Table 1). In 2002 and 2003, water potentials varied between -15 and $-40 \mathrm{hPa}$ in the subsoils and between -50 and $-300 \mathrm{hPa}$ in the topsoils most of the time. The exception was a purposely induced drought period in June 2002 with water potentials going shortly down to $-550,-350$, and $-750 \mathrm{hPa}$ in the calcareous subsoil, acidic subsoil and topsoil, respectively (data not shown). Drainage discharge was large (Table 1) except for the induced drought period. In both years, soil moisture in the lower part of the subsoil was higher in the acidic subsoil than in the calcareous subsoil (Table 1). In 2002, this was also the case for the drainage discharge.

\subsection{Drainage Discharge and Soil Moisture} in the Lysimeters Receiving Natural Precipitation

Weather conditions during the first and second summer allowed the lysimeters with natural precipitation to remain sufficiently moist throughout the growing season to allow collection of drainage water. From May through August 2000, there was even more drainage from these lysimeters than from the irrigated lysimeters (Table 1). However, there was 
almost no drainage discharge in August and September 2002 and during the entire warm summer 2003. In 2001, 2002 and 2003, discharge from the lysimeters with natural precipitation was significantly lower than in the corresponding irrigated lysimeters except for the calcareous subsoil in 2002 (Table 1).

\subsection{Chemical Composition of Drainage Water}

The chemical data of the drainage water samples from the different sampling dates were subjected to a multivariate analysis of variance (MANOVA) to test the influence of subsoil type, irrigation vs. natural precipitation, irrigation type, and topsoil contamination (comparing lysimeters with and without metal dust added to the topsoil). This showed that the chemical composition of the drainage water differed mainly between acidic and calcareous subsoil, and, in the first year in addition between irrigated and nonirrigated lysimeters (Table 3). Only $\mathrm{pH}$ was influenced by irrigation $\mathrm{pH}$ and somewhat by topsoil contamination. Therefore, irrespective of topsoil contamination or irrigation $\mathrm{pH}$, data were pooled for a given subsoil and watering treatment (artificial irrigation vs. natural precipitation) (Figs. 1, 2 and 3).

Below calcareous subsoil, the electrical conductivity as well as the concentrations of nitrate and sulfate were higher during an initial phase of 9, 12 and 10 months, respectively, than during the later stages of the experiment (Fig. 1). These effects were smaller for the lysimeters receiving only natural precipitation (Fig. 1). Below acidic subsoil, conductivity and nitrate concentrations were elevated during an initial phase of 6 months with significantly smaller conductivity values for lysimeters receiving only natural precipitation.

During the second phase, below calcareous subsoil, electrical conductivity exhibited a regular sea- sonal variability with maxima in October, which was the same in irrigated and non-irrigated lysimeters. Below acidic subsoil, conductivity decreased slightly and constantly. This change was significant only for the irrigated lysimeters however (Table 4). In contrast to constantly low nitrate concentrations during the second phase of the experiment below acidic subsoil and calcareous subsoil in non-irrigated lysimeters, nitrate below the irrigated lysimeters with calcareous subsoil remained low for one and a half years, but exhibited small seasonal increases in winter 2002/ 2003 and in winter 2003/2004 (Fig. 1b, inset). The latter were responsible for a small increasing trend (Table 4). From the second year on the sulfate concentrations exhibited a seasonal variation with maxima in early winter below calcareous subsoil in both irrigated and non-irrigated lysimeters. Below irrigated and non-irrigated lysimeters with acidic subsoil, sulfate decreased over the entire observation period (Fig. 1c; Table 4).

Dissolved organic carbon (DOC) concentrations were somewhat elevated during the first year below calcareous subsoil (Fig. 2a). Later, the DOC concentrations below calcareous subsoil adopted a seasonal variation with maxima in late summer on top of a trend to decrease (Table 4). Below acidic subsoil, DOC concentrations decreased continuously during the entire experiment without distinctive initial phase and without seasonal fluctuations. The $\mathrm{pH}$ below calcareous subsoil was approximately 8 for the first 5 months and varied between 8.2 and 8.7 thereafter (Fig. 2b), with no difference between irrigated and non-irrigated lysimeters. The $\mathrm{pH}$ for irrigated lysimeters with acidic subsoil was also approximately 8 for the first 5 months, followed by a drop to seasonally varying values between 6 and 7.5 with maxima in summer. The drainage water below non-irrigated lysimeters with acidic subsoil showed a seasonal
Table 3 Results of MAN OVA for the drainage water samples of all sampling dates $(n=40) /$ sampling dates of the first year (4.7.2000 18.5.2001; $n=13) ; * * * p<$ $0.0001, * * p<0.001, * p<$ $0.01, n s$ not significant

\begin{tabular}{lllll}
\hline & $\begin{array}{l}\text { Subsoil } \\
\text { type }\end{array}$ & $\begin{array}{l}\text { Irrigation vs. natural } \\
\text { precipitation }\end{array}$ & $\begin{array}{l}\text { Irrigation } \\
\text { type }\end{array}$ & $\begin{array}{l}\text { Topsoil } \\
\text { contamination }\end{array}$ \\
\hline Conductivity & $* * * / * * *$ & $\mathrm{~ns} / * *$ & $\mathrm{~ns} / \mathrm{ns}$ & $\mathrm{ns} / \mathrm{ns}$ \\
$\mathrm{NO}_{3}$ & $* * * / * * *$ & $\mathrm{~ns} / \mathrm{ns}$ & $\mathrm{ns} / \mathrm{ns}$ & $\mathrm{ns} / \mathrm{ns}$ \\
$\mathrm{SO}_{4}$ & $\mathrm{~ns} / * *$ & $\mathrm{~ns} / *$ & $\mathrm{~ns} / \mathrm{ns}$ & $\mathrm{ns} / \mathrm{ns}$ \\
$\mathrm{DOC}$ & $* * * / * * *$ & $\mathrm{~ns} / \mathrm{ns}$ & $\mathrm{ns} / \mathrm{ns}$ & $\mathrm{ns} / \mathrm{ns}$ \\
$\mathrm{pH}$ & $* * * / * * *$ & $* * * / * * *$ & $* * * / \mathrm{ns}$ & $* / \mathrm{ns}$ \\
$\mathrm{Cu}$ & $* * * / * * *$ & $* / \mathrm{ns}$ & $\mathrm{ns} / \mathrm{ns}$ & $\mathrm{ns} / \mathrm{ns}$ \\
$\mathrm{Zn}$ & $* * * / * * *$ & $\mathrm{~ns} / \mathrm{ns}$ & $\mathrm{ns} / \mathrm{ns}$ & $\mathrm{ns} / \mathrm{ns}$ \\
& & & &
\end{tabular}


Fig. 1 Electrical conductiv ity (a), nitrate (b), and sul fate concentrations $(c)$ in the drainage water. Shown are mean values with standard deviations for irrigated lysimeters ( $n=4$ for pooled samples per treatment) and lysimeters receiving natural precipitation throughout ( $n=2$ for individual samples per treatment); the grey parts indicate the time period with irrigation

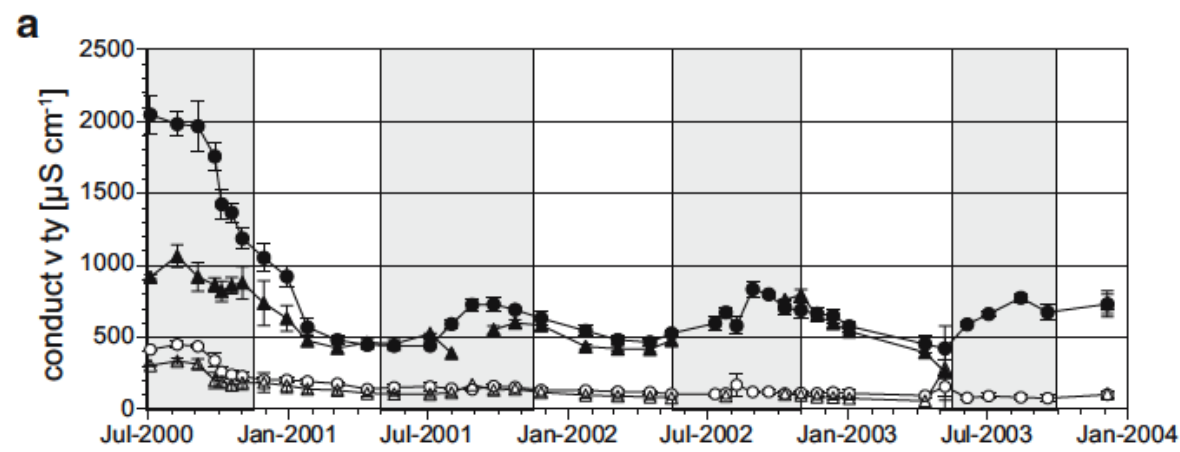

b

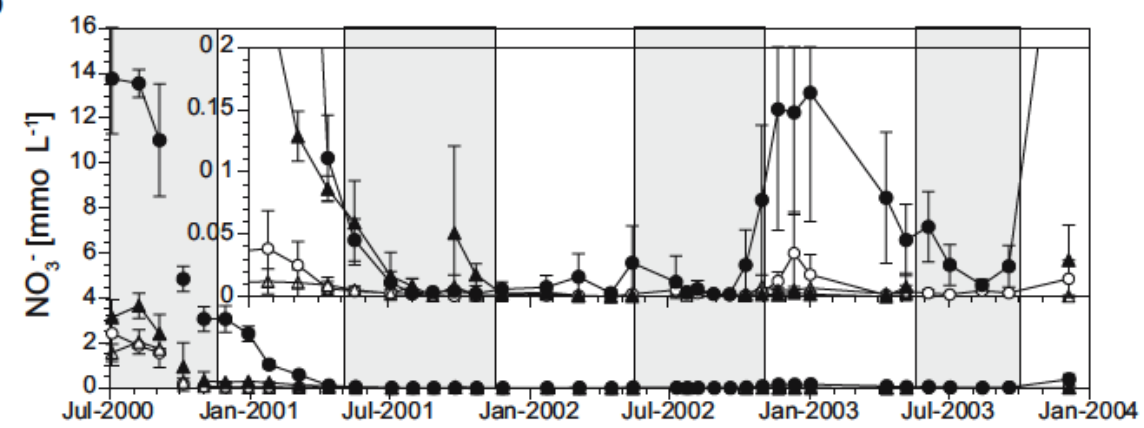

C

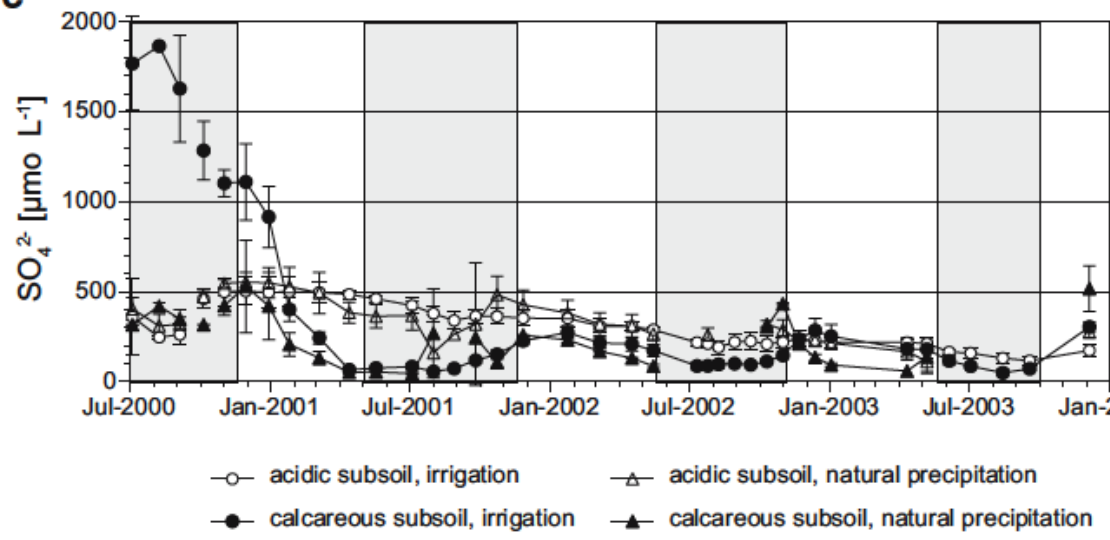

variation throughout the experiment with no distinct initial phase.

Copper concentrations were generally larger below calcareous subsoil than below acidic subsoil. Below calcareous subsoil, $\mathrm{Cu}$ varied similar to DOC (Fig. 3a, Table 4), and there was a good correlation between logarithmic concentrations of $\mathrm{Cu}$ and DOC $\left(R^{2}=0.58\right.$; $p<0.0001)$. Below acidic subsoil, $\mathrm{Cu}$ concentrations increased gradually during the first year and remained constant for the rest of the experiment. The increase during the first year was negatively correlated with $\mathrm{pH}$ (logarithmic concentrations; $R^{2}=0.33 ; p=0.003$ ).
Zinc concentrations below calcareous subsoil showed a seasonal variation during the entire experiment with maxima in summer (Fig. 3b). The logarithmic $\mathrm{Zn}$ concentrations were correlated mainly with $\mathrm{pH}$ (negative correlation; $R^{2}=0.23 ; p<0.0001$ ) and logarithmic conductivity $\left(R^{2}=0.13 ; p=0.003\right)$. Zinc below acidic subsoil was correlated mainly with sulfate (logarithmic concentrations; $R^{2}=0.36 ; p<$ 0.0001 ). An initial phase of about 3 months was characterized by elevated $\mathrm{Zn}$ concentrations below nonirrigated and distinctly low concentrations below irrigated lysimeters. Later, $\mathrm{Zn}$ concentrations below 
Fig. 2 Dissolved organic carbon concentrations (a), and $\mathrm{pH}(\mathbf{b})$ in the drainage water. Shown are mean val ues with standard deviations for irrigated lysimeters $(n=4$ for pooled samples per treatment) and lysimeters receiving natural precipita tion throughout ( $n=2$ for individual samples per treatment); the grey parts indicate the time period with irrigation

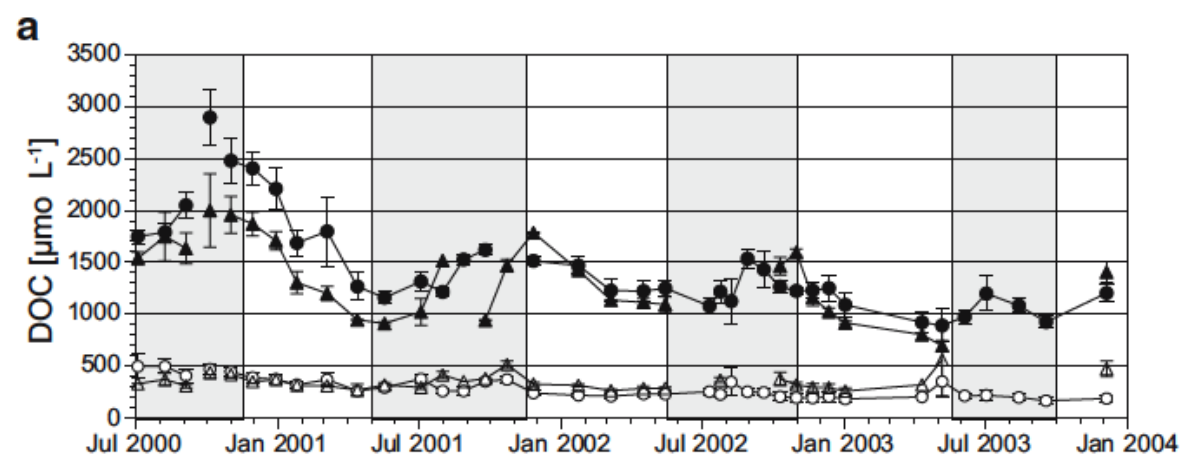

b

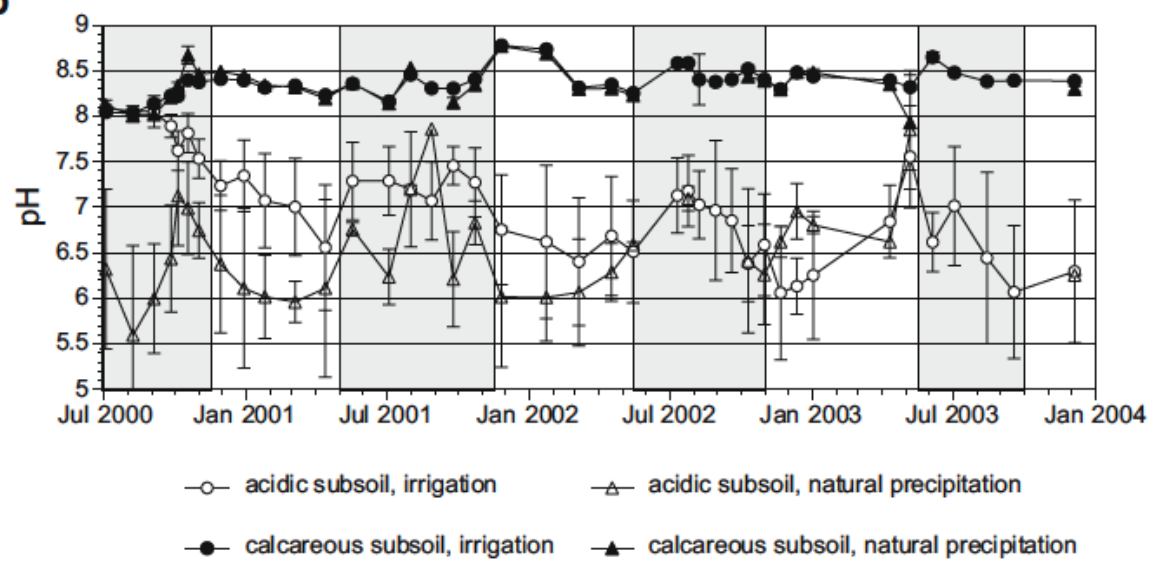

acidic subsoil decreased more or less continuously (Fig. 3b, Table 4).

\subsection{Soil Respiration}

Figure 4 shows soil respiration measurements taken in August of each year. In the first year, respiration was significantly larger from the lysimeters receiving natural precipitation than from the irrigated lysimeters, in 2001 this was the case only for the lysimeters with acidic subsoil. Mostly, there were no significant differences between the respiration from lysimeters with calcareous and acidic subsoils. The exception was 2001, when respiration from the irrigated lysimeters with calcareous subsoil was larger than from the irrigated lysimeters with acidic subsoil, while it was the other way around for the nonirrigated lysimeters. Average respiration from the irrigated lysimeters correlated quite well with the average soil moisture in August in the topsoil: $q \mathrm{CO}_{2}$ $\left[\mu \mathrm{mol} \mathrm{m}{ }^{2} \mathrm{~s}^{1}\right]=8.2+0.023 \times h$ [hpa] $\left(R^{2}=0.58 ; p=\right.$ $0.029)$. Correlations with water potentials in the subsoil were worse with $R^{2}=0.16$ at $38 \mathrm{~cm}$ depth and $R^{2}=0.10$ at $88 \mathrm{~cm}$ depth.

\section{Discussion}

4.1 Comparison Between Irrigated and Non-irrigated Lysimeters; Soil Moisture in the Irrigated Lysimeters

The initial electrical conductivity values below both subsoils and the initial nitrate and sulfate concentrations below calcareous subsoils were much less elevated in the drainage water of the lysimeters receiving natural precipitation throughout the year than in those receiving artificial irrigation during the growing season. This may be explained by the different moisture and temperature regime during the last phase of installation and the first growing season. The lysimeters in the OTC received no water at all for 2 months during the establishment of the contamination in the topsoil, whereas, at the same time, the lysimeters outside the OTC were exposed to natural 
Fig. 3 Copper (a), and zinc concentrations (b) in the drainage water. Shown are mean values with standard deviations for irrigated lysimeters $(n=4$ for pooled samples per treatment) and lysimeters receiving natural precipitation throughout ( $n=2$ for individual samples per treatment); the grey parts indicate the time period with irrigation a

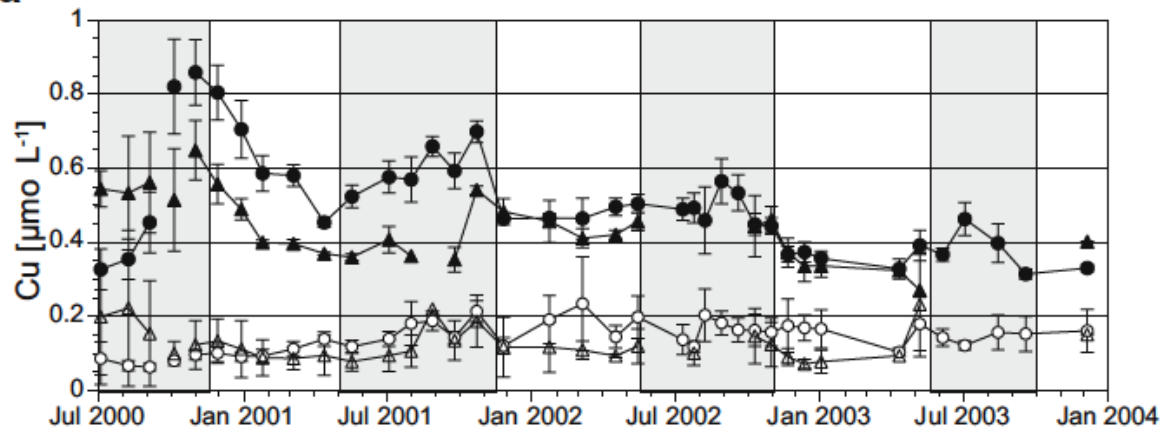

b

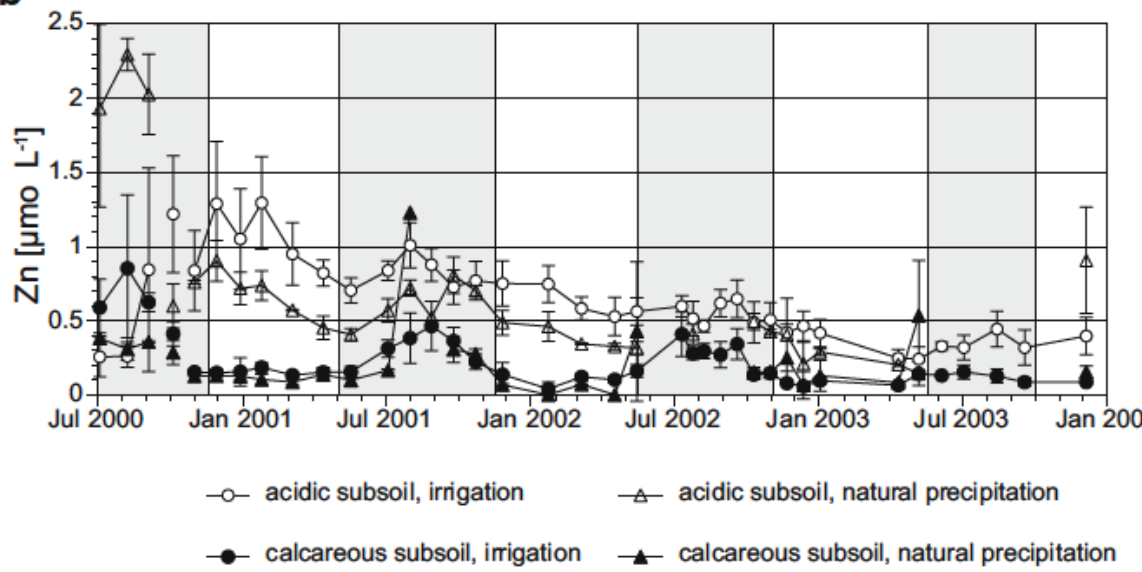

precipitation of $2.45 \mathrm{~L} \mathrm{~m}^{2}$ day ${ }^{1}$ (Table 1). In addition, there was more natural precipitation than irrigation during the first part of the growing season 2000 (Table 1). This marked difference in soil moisture regime between irrigated and non-irrigated lysimeters for about half a year very likely also explains why during the first phase of the experiment high $\mathrm{pH}$ values of about 8 below acidic subsoil were observed only below the irrigated lysimeters. These high $\mathrm{pH}$ values indicate the occurrence of carbonate impurities in the quartz drainage packing that were dissolved after passage of sufficient drainage water.

The generally drier conditions in the irrigated lysimeters with calcareous subsoils than with acidic subsoils during the growing seasons 2001, 2002, and 2003 can be attributed to the larger water consumption

Table 4 Change in drainage water composition between July 2001 and July $2003 ;{ }^{* * *} p<0.0001,{ }^{* *} p<0.001,{ }^{*} p<0.01,\left({ }^{*}\right) p<0.05$, ns not significant

\begin{tabular}{|c|c|c|c|c|}
\hline & $\begin{array}{l}\text { Acidic subsoil, } \\
\text { irrigation }\end{array}$ & $\begin{array}{l}\text { Acidic subsoil, natural } \\
\text { precipitation }\end{array}$ & $\begin{array}{l}\text { Calcareous subsoil, } \\
\text { irrigation }\end{array}$ & $\begin{array}{l}\text { Calcareous subsoil, natural } \\
\text { precipitation }\end{array}$ \\
\hline $\begin{array}{l}\text { conductivity }\left[\mu \mathrm{S} \mathrm{cm}{ }^{1}\right. \\
\left.\text { year }^{1}\right]\end{array}$ & $24 *$ & 1 & 7 & +6 \\
\hline $\mathrm{NO}_{3}\left[\mu \mathrm{mol} \mathrm{L}{ }^{1}\right.$ year $\left.{ }^{1}\right]$ & +4 & +0.4 & $+45^{*}$ & 10 \\
\hline $\mathrm{SO}_{4}\left[\mu \mathrm{mol} \mathrm{L}^{1}\right.$ year $\left.{ }^{1}\right]$ & $116^{* * *}$ & $92(*)$ & +19 & 9 \\
\hline $\mathrm{DOC}\left[\mu \mathrm{mol} \mathrm{L}^{1}\right.$ year $\left.{ }^{1}\right]$ & $45\left(^{*}\right)$ & 2 & $213^{* *}$ & 227 \\
\hline $\mathrm{pH}\left[\right.$ year $\left.{ }^{1}\right]$ & 0.22 & +0.18 & +0.04 & 0.06 \\
\hline $\mathrm{Cu}\left[\mu \mathrm{mol} \mathrm{L}^{1}\right.$ year $\left.{ }^{1}\right]$ & 0.02 & 0.01 & $0.12 * * *$ & $0.06\left(^{*}\right)$ \\
\hline $\mathrm{Zn}\left[\mu \mathrm{mol} \mathrm{L}^{1}\right.$ year $\left.^{1}\right]$ & $0.31^{* * *}$ & $0.25^{* * *}$ & $0.11(*)$ & 0.12 \\
\hline
\end{tabular}


Fig. 4 Soil respiration ( $\mathrm{col}$ umns) and average water potential in the topsoil (bubbles) measured in $\mathrm{Au}$ gust; filled and empty bub bles refer to lysimeters with calcareous and acidic sub soil, respectively

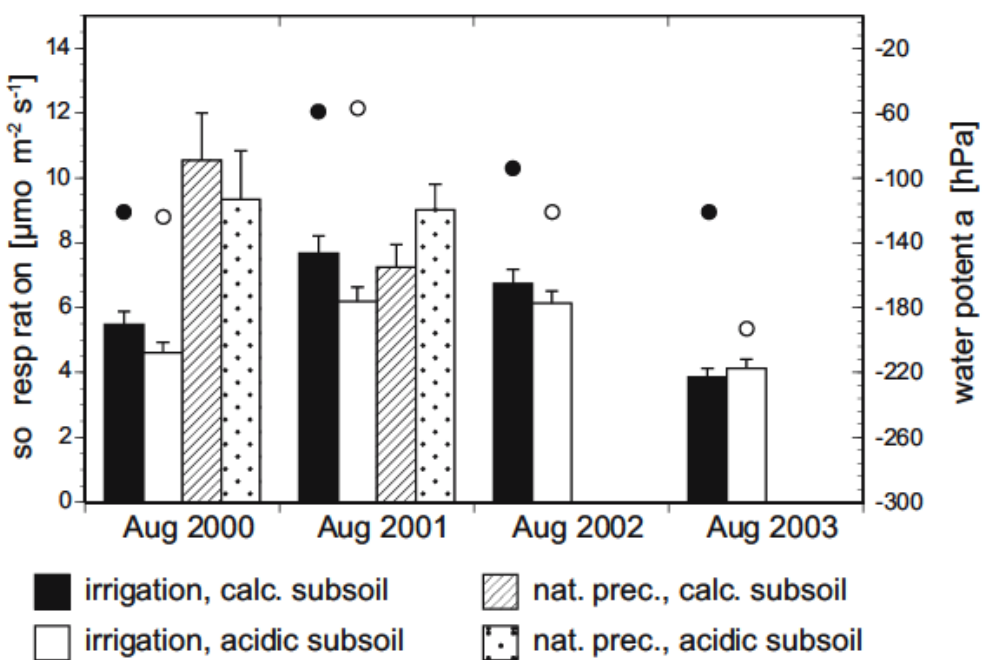

by the plants associated with the larger biomass production (Menon et al. 2005; Hermle et al. 2006).

\subsection{Drainage Water Chemistry Below Irrigated Lysimeters, General Considerations}

A bromide tracer experiment with the calcareous subsoil, carried out in an earlier study, revealed that a small part of water moved in larger pores at a velocity of about $25 \mathrm{~mm}$ day ${ }^{1}$, while the main part drained at velocities between 3 and $10 \mathrm{~mm}$ day ${ }^{1}$ (Sonnleitner et al. 2003). From this it can be concluded that the chemical composition of the drainage water can be assumed to be determined mainly by equilibrium with the deeper subsoil. Considering the similar texture of the two subsoils, the same can be assumed for the drainage water leaving the acidic subsoil.

Nowack et al. (2006) showed, based on the analysis of soil solution samples collected during the last 2 years of the experiment using tension lysimeters, that the addition of the HM dust had led to elevated concentrations of $\mathrm{Cu}, \mathrm{Zn}, \mathrm{Cd}$ and $\mathrm{Pb}$ in the topsoil (10 cm depth), but not in the subsoil solution (40 and $70 \mathrm{~cm}$ depth). Effects of the topsoil contamination were therefore restricted mainly to the topsoil and are not discussed in the following.

Based on electrical conductivity as a sum parameter representing ionic strength, we can distinguish two phases: an initial phase with rapid chemical changes during about 9 months, and a second phase characterized by gradual chemical changes overlaid by seasonal variations. The generally higher electrical conductivity below the calcareous subsoils can be attributed to the dissolution of carbonates. The seasonal increase of conductivity below calcareous subsoils in autumn indicates mineralisation of soil organic matter (SOM). This is probably much stronger below calcareous subsoils than below acidic subsoils because of the higher SOM content and higher $\mathrm{pH}$ of the calcareous subsoils.

\subsection{Nitrate in the Drainage Water Below Irrigated Lysimeters}

The initial flush of nitrate can be ascribed to the mineralisation of organic nitrogen (followed by nitrification) exposed to microbial decomposition after the disruption of soil structure in the course of soil relocation and rewetting of the soil at the onset of the experiment (Birch 1958). Concentrations were up to 100 times and 20 times higher than the combined input of ammonium and nitrate by irrigation (140 $\mu \mathrm{mol} \mathrm{L}^{1}$ ) below calcareous and acidic subsoil, respectively. Below the calcareous subsoil, the nitrification during the initial phase was so strong that the related proton production probably exceeded the buffering capacity of the soil and was therefore responsible for the slightly lower $\mathrm{pH}$ value during the initial phase. The difference between the calcareous and acidic subsoil can be ascribed to the marked difference in total $\mathrm{N}$ and soil organic carbon content between the two subsoils and the less favorable conditions for microorganisms resulting from the lower $\mathrm{pH}$ and nutrient contents in the acidic subsoil 
(Table 2). The concentration of $12 \mathrm{mmol} \mathrm{L}^{1}$ nitrate below the calcareous subsoil is similar to the increase of the initial nitrate concentration in soil solution during a pot experiment caused by fertilising a homogenized agricultural topsoil (weakly acidic clay loam) with $100 \mu \mathrm{g} / \mathrm{g}$ ammonium (Johnson et al. 1995). The latter study was carried out at $25^{\circ} \mathrm{C}$, i.e. at a somewhat higher temperature than during our experiment. With an irrigation to ensure a constant free drainage, the elevated initial nitrate concentrations came down to about $500 \mu \mathrm{mol} \mathrm{\textrm {L } ^ { 1 }}$ within 8 months. In a column study with homogenized material from an acidic sandy loam from a forest topsoil rich in soil organic carbon and total N (2.4\%) at a temperature of $10^{\circ} \mathrm{C}$, Ross and Hales (2003) observed initial nitrate concentrations of about $5 \mathrm{mmol}$ $\mathrm{L}^{1}$. With a regular weekly irrigation of $25 \mathrm{~mm}$, i.e. similar as the average irrigation in our experiment during the first summer, nitrate concentrations decreased much more slowly than in the one of Johnson et al. (1995). After 2 years, nitrate concentrations were still at about $1.5 \mathrm{mmol} \mathrm{L}{ }^{1}$. The comparison with these earlier studies suggests, that the intensity of the initial nitrification flush depends both on the SOM content and the temperature, while the rate at which the elevated nitrate concentrations decrease is determined by the rate of irrigation and possibly by the temperature.

The seasonal maxima of nitrate in the drainage water below calcareous subsoils in the third and fourth winter roughly correspond to the total nitrogen input during these periods, during which there was no uptake by plants and microorganisms. The lack of this maximum in the second winter indicates a strong depletion of available nitrogen during the initial mineralisation burst. In the same line of argumentation, the much smaller increase in leached nitrate during the second, third and fourth winter below acidic subsoils than below calcareous subsoils suggests, that, despite its relatively low intensity, the initial nitrification flush in the acidic subsoil had led to a strong depletion of available nitrogen.

\subsection{Sulfate in the Drainage Water Below Irrigated Lysimeters}

In contrast to nitrate, sulfate concentrations were orders of magnitude higher than input concentrations (3 $\mu \mathrm{mol} \mathrm{L}{ }^{1}$ ) over the entire observation period independently of the type of subsoil. In line with the hypothesized nitrogen mineralization above, the elevated sulfate concentrations below the calcareous subsoil during the initial phase can be attributed to mineralisation of SOM that became exposed by disruption of soil structure as a result of soil relocation. The winter maxima of sulfate leaching below calcareous subsoils during the second phase of the experiment paralleled the seasonality of DOC, and thus can be explained also by mineralisation of organic sulfur. The high sulfate concentrations below the acidic subsoils can be attributed either to mineralisation of organic sulfur, or to leaching of sulfate previously accumulated in the soils at their original site. All soils were taken from suburban areas in Switzerland that were subjected to high sulfate depositions during the nineteen seventies and eighties, as were most such areas in central Europe (Ferrier et al. 2001). Leaching of sulfate, that was accumulated during the time period of high atmospheric input of sulfur, has been observed widely for acidic forest soils (Alewell and Matzner 1993). The rather rapid continuous decrease of the sulfate concentrations below acidic subsoil during the second phase of our experiment could have resulted from depletion of the mobilisable sulfate pool, or from the formation of new aggregates protecting adsorbed sulfate or organic sulfur.

\subsection{Dissolved Organic Carbon in the Drainage Water Below Irrigated Lysimeters}

Both the generally much higher DOC concentrations below calcareous subsoil than below acidic subsoil, and the more pronounced seasonal variations below the calcareous subsoils can be attributed, firstly, to the much higher organic carbon content of the calcareous subsoil, and secondly to the probably less favorable conditions for microorganisms in the acidic subsoil because of the lower $\mathrm{pH}$.

The seasonal variation of DOC below calcareous subsoil corresponds to the expected patterns in the activity of SOM degrading microorganisms, which are stimulated by plant growth and high temperatures with maximum activity in late summer. The decrease in DOC in the drainage water during winter on one hand reflects reduced microbial activity, and, on the other hand, retarded leaching of DOC produced during the time of maximum microbial activity. Water 
flux as the governing force is less likely, since the highest DOC concentrations in autumn coincide with large water flux, and the lowest DOC concentrations at the beginning of the growing season with dry soil conditions. This is supported by the small effect of irrigation rate on DOC leaching from the subsoil in a column experiment using the same topsoil and subsoil as in our lysimeter experiment (Zhao et al. 2007) and by the mainly negative correlations between DOC concentrations and water flux observed by Strand et al. (2002). Considering the initial nitrogen mineralization flush, the somewhat enhanced DOC concentrations below calcareous subsoil in the first autumn can be ascribed to SOM mobilisation due to structural disruption during soil relocation (Birch 1958; Franzluebbers 1999). The gradual decrease of DOC over the entire experiment in both subsoils could be explained by a decrease of the rate of SOM degradation with time due to the formation of new aggregates, and/or by a gradual depletion of the SOM pool during the experiment. Indeed, the $\mathrm{C}_{\text {org }}$ content of the calcareous subsoil decreased somewhat from $11.2 \mathrm{~g} \mathrm{~kg}^{1}$ at the beginning (Table 2) to $9.7 \mathrm{~g} \mathrm{~kg}^{1}$ at the end of the experiment. Apart from the mineralisation burst during the first phase of the experiment, this depletion can be explained by the lack of fresh carbon input by litter fall. The aboveground biomass of poplar, willow and the understorey plants was harvested every year in September (Hermle et al. 2006).

\subsection{Soil Respiration}

The better correlation of soil respiration with soil moisture in the topsoil than with the one in the subsoil, and the lack of a clear dependence of respiration on the type of subsoil, suggests that this parameter is mainly governed by topsoil parameters. This is in good agreement with the larger root density in the topsoils than in the subsoils (Menon et al. 2005) indicating a higher microbial activity in the topsoil. Nevertheless, one could have expected that an enhanced $\mathrm{CO}_{2}$ production during the initial mineralisation burst would have led to strongly elevated soil respiration, in particular from lysimeters with calcareous subsoil. The fact, that this was not observed in August 2000, can be explained with earlier findings that respective $\mathrm{CO}_{2}$ flushes, in contrast to increased nitrate production, subside a few days after rewetting (Franzluebbers 1999).
In addition, based on the correlation of respiration with soil moisture in the topsoil, the higher respiration from lysimeters receiving natural precipitation in August 2000 supports the assumption of higher soil moisture in these lysimeters than in the irrigated lysimeters.

\subsection{Trace Metals in the Drainage Water Below Irrigated Lysimeters}

Since there was no influence of the HM contamination in the topsoil on the drainage water chemistry, the metal concentrations in the drainage water reflect the solubility of lithogenic HM in the subsoil. Overall, the chemical changes induced by aggregate destruction and/or drying and rewetting had only little consequences on the HM concentrations in the drainage water. The good correlation of $\mathrm{Cu}$ concentrations below calcareous subsoil with DOC (Rais 2005) and the generally higher $\mathrm{Cu}$ concentrations below calcareous than acidic subsoil, indicate strong complexation of $\mathrm{Cu}$ with dissolved organic matter, which is in agreement with the well known high affinity between $\mathrm{Cu}$ and DOC (McBride 1994). The positive correlation between $\mathrm{Zn}$ and electrical conductivity below calcareous subsoil, and the correlation between $\mathrm{Zn}$ and sulfate below acidic subsoil suggest an influence of cation exchange. Higher ionic strength means higher concentration of cations competing with $\mathrm{Zn}$ in the solution for cation exchange sites on the soil surface. Unfortunately, the concentrations of major cations, in particular $\mathrm{Ca}$ and $\mathrm{Mg}$, were not measured. The occurrence of low $\mathrm{Cu}$ and $\mathrm{Zn}$ concentrations during the first months below irrigated lysimeters with acidic subsoil may have been caused by the precipitation of leached metals in the drainage layer due to carbonate impurities. However, the strongly elevated initial $\mathrm{Zn}$ concentrations below the non-irrigated lysimeters with acidic subsoil, for which $\mathrm{pH}$ values indicated no such artefact, suggest that the solubility of this metal was somehow related to the disturbance of soil structure.

\section{Conclusions}

Our study with refilled lysimeters revealed two distinct soil conditioning phases that can be related to structural disturbance of the soil material during 
relocation. During an initial phase, the nitrogen and sulfur chemistry of a soil can be seriously affected by a mineralisation flush upon rewetting the dried soil which is enhanced by increased accessability of mineralisable nitrogen and sulfur in destroyed aggregates. With respect to nitrogen, this corroborates previous findings. In our study, the effects were significantly larger in the lysimeters with calcareous subsoil than in those with acidic subsoil. This very likely can be attributed to the higher content in SOM and the higher $\mathrm{pH}$ of the calcareous subsoil. The second phase was characterised by a gradual decrease in DOC and sulfate, in particular in the acidic subsoil. This decrease may partly be attributed to depletion of pools made accessible previously during aggregate destruction, or to the formation of new aggregates.

Based on our results, it can be concluded that large refilled lysimeters can be used for many purposes without risk of compromised results, if a conditioning phase of about 1 year with sufficiently moist soil conditions is respected. Nevertheless, gradual changes in soil chemical characteristics still occur after this initial phase. Our results have implications also for the recultivation of sites using relocated soils. Nitrate flushes occurring after soil restoration may negatively affect the quality of water resources. Desiccation of stored soil should be avoided to minimise the extent of the mineralisation flush during recultivation. Temporary soil deposits are often kept dry to avoid degradation due to waterlogging (Zwölfer et al. 1991).

Acknowledgements The soils were selected and collected by W. Attinger (ETH Zurich). He also incorporated the metal dust, and installed and read out the tensiometers. The irrigation system was programmed and operated by W. Landolt and P. Bleuler (WSL). The staff of the WSL garden, as well as M. Lautenschläger and D. Tarjan (WSL) filled the lysimeters and planted the vegetation. Help with drainage water collection was provided by A. Sparacino, A. Zürcher, D. Christen and B. Peter (WSL). The latter three, the central analytical laboratory at WSL and Lu Zhao (ETH Zurich) performed the chemical analyses. This research was supported by grant Nr. 21 61842.00 of the Swiss National Science Foundation and by funds of the Swiss Federal Research Institute WSL and the ETH Zurich.

\section{References}

Abrahamsen, G., \& Erstad, K. J. (1995). Nutrient balance in Scots pine (Pinus sylvestris L.) forest. 1. Design of experiments. Water, Air and Soil Pollution, 85, 1125 1130 .
Alewell, C., \& Matzner, E. (1993). Reversibility of soil solution acidicity and of sulfate retention in acidic forest soils. Water, Air and Soil Pollution, 71, 155165.

Bergström, L., \& Stenström, J. (1998). Environmental fate of chemicals in soil. Ambio, 27, 1623.

Birch, H. F. (1958). The effect of soil drying on humus decomposition and nitrogen availability. Plant and Soil, 10, 931.

Brunner, I., Luster, J., Günthardt Goerg, M. S., \& Frey, B. (2007). Heavy metal accumulation and phytostabilisation potential of tree fine roots in a contaminated soil. Environmental Pollution, DOI 10.1016/j.envpol.2007.07.006.

Ferrier, R. C., Jenkins, A., Wright, R. F., Schopp, W., \& Barth, H. (2001). Hydrological assessment of recovery of European surface waters from acidification 1970 2000: An introduction to the special issue. Earth Systems Sciences, 5, 274282.

Franzluebbers, A. J. (1999). Potential C and N mineralization and microbial biomass from intact and increasingly disturbed soils of varying texture. Soil Biology and Biochemistry, 31, 10831090.

Frey, B., Stemmer, M., Widmer, F., Luster, J., \& Sperisen, C. (2006). Microbial characterization of a heavy metal contaminated soil by means of woody plants. Soil Biology \& Biochemistry, 38, 17451756.

Healy, R. W., Striegel, R. G., Russell, T. F., Hutchinson, G. L., \& Livingston, G. P. (1996). Numerical evaluation of static chamber measurements of soil atmosphere gas exchange: Identification of physical processes. Soil Science Society of America Journal, 60, 740747.

Hermle, S., Günthardt Goerg, M. S., \& Schulin, R. (2006). Effects of metal contaminated soil on the performance of young trees growing in model ecosystems under field conditions. Environmental Pollution, 144, 703714.

Hermle, S., Vollenweider, P., Günthardt Goerg, M., McQuattie, C. J., \& Matyssek, R. (2007). Leaf responsiveness of Populus tremula and Salix viminalis to soil contaminated with heavy metals and acidic rainwater. Tree Physiology, 27, 15171531 .

Johnson, D. W., Walker, R. F., \& Ball, J. T. (1995). Lessons from lysimeters: Soil $\mathrm{N}$ release from disturbance compro mises controlled environment study. Ecological Applica tions, 5, 395400 .

Landolt, W. (2001). Beschreibung der Versuchsanlage im Projekt "ICAT Birmensdorf'. In C. Brunold, P. W. Balsiger, J. B. Bucher, \& C. Körner (Eds.), Wald und $\mathrm{CO}_{2}$. Ergebnisse eines ökologischen Modellversuchs (pp. 85 95). Birmensdorf: Swiss Federal Research Institute WSL, Bern: Haupt.

Marthaler, H. P., Vogelsanger, W., Richard, F., \& Wierenga, P. J. (1983). A pressure transducer for field tensiometers. Soil Science Society of America Journal, 47, 624627.

McBride, M. B. (1994). Environmental chemistry of soils. New York: Oxford University Press.

Menon, M., Hermle, S., Abbaspour, K. C., Günthardt Goerg, M. S., Oswald, S., \& Schulin, R. (2005). Water regime of metal contaminated soil under juvenile forest vegetation. Plant and Soil, 271, 227241.

Miller, E. K., Huntington, T. G., Johnson, A. H., \& Friedland, A. J. (1992). Aluminum in soil solutions from a subalpine spruce fir forest at Whiteface Mountain, New York. Journal of Environmental Quality, 21, 345352. 
Nowack, B., Rais, D., Frey, B., Menon, M., Schulin, R., Günthardt Goerg, M. S., \& Luster, J. (2006). Influence of heavy metal contamination on soil parameters in a lysimeter experiment designed to evaluate phytostabiliza tion by afforestation. Forest Snow and Landscape Re search, 80, 201211.

Powlson, D. S. (1980). The effects of grinding on microbial and non microbial organic matter in soil. Journal of Soil Science, 31, 7785.

Rais, D. (2005). Soil solution chemistry in a heavy metal contaminated forest model ecosystem. ETH Zurich, Diss. ETH Nr. 16091.

Ross, D. S., \& Hales, H. C. (2003). Sampling induced increases in net nitrification in the Brush Brook (Vermont) water shed. Soil Science Society of America Journal, 67, 318 326.

Schmidt, M., \& Bannick, C. G. (1996). Soil protection strategies in Brandenburg Management of waste recy cling on devastated areas subject to recultivation (soil protection in recultivation areas). Water, Air and Soil Pollution, 91, 5978.
Sogn, T. A., \& Abrahamsen, G. (1998). Effects of $\mathrm{N}$ and $\mathrm{S}$ deposition on leaching from an acidic forest soil and growth of Scots pine (Pinus sylvestris L.) after 5 years of treatment. Forest Ecology and Management, 103, 177 190.

Sonnleitner, M. A., Abbaspour, K. C., \& Schulin, R. (2003). Hydraulic and transport properties of the plant soil system estimated by inverse modelling. European Journal of Soil Science, 54, 127138.

Strand, L. T., Abrahamsen, G., \& Stuanes, A. O. (2002). Leaching from organic matter rich soils by rain of different qualities: I. Concentrations. Journal of Environ mental Quality, 31, 547556.

Zhao, L., Schulin, R., Weng, L. P., \& Nowack, B. (2007). Coupled mobilization of dissolved organic matter and metals $(\mathrm{Cu}$ and $\mathrm{Zn})$ in soil columns. Geochimica and Cosmochimica Acta, 71, 34073418.

Zwölfer, F., Geiss, M., Adam, P., Heinrichsmeier, K., \& Herrmann, H. (1991). Erhaltung fruchtbaren und kultur fähigen Bodens bei Flächeninanspruchnahmen. Stuttgart: Ministerium für Umwelt Baden Württemberg. 